\title{
Pengaruh Pengetahuan, Kontrol Diri terhadap Perilaku Seksual Pranikah di Kalangan Remaja SMK di Surabaya
}

\author{
Nita Istiqomah, Hari Basuki Notobroto \\ Departemen Biostatistika dan Kependudukan \\ Fakultas Kesehatan Masyarakat Universitas Airlangga \\ J1. Mulyorejo Kampus C Unair, Surabaya, 60115 \\ Alamat Korespondensi: \\ Nita Istiqomah, E-mail: Nietha.isti@yahoo.co.id
}

\begin{abstract}
The premarital sexual behavior adolescent has become a social problem in the community. Free sexual behavior are various ranging from feeling of attraction to the opposite sex, dating, kissing, holding partsof the body that are sensitive until sexual intercourse. Two factors that can influence sexual behavior are knowledge and self control. Adolescent who have high knowledge and self control tend to not perform sexual behavior. The purpose of this study was to analyze the effect of knowledge and premarital sexual behavior self control in adolescent of SMK in Surabaya. This study was performed using cross sectional study design. The study population was students of class XI SMK in Surabaya. Subjects were selected by proportional stratified random sampling. Sample was 83 students. Data analysis was performed using chi square test $(\alpha=0.05)$. The results of this study were self-control influenced knowledge $(p=0.000 ; P R=11.000)$, knowledge influenced premarital sexual behavior $(p=0.000$; $P R=10.607)$ and self-control influenced premarital sexual behavior $(p=0.000 ; P R=46.970)$. The conclusion of this research is variables knowledge and self-control influence premarital sexual behavior SMK in Surabaya increasing increase knowledge of adolescent in relation to premarital sexual behavior before marriage through counseling in Generation Program Plan (GENRE). Genre was can be a alternative solution to decrease premarital sexual behavior.
\end{abstract}

Keywords: knowledge, self-control, premarital sexual behavior

\begin{abstract}
ABSTRAK
Perilaku seksual pranikah di kalangan remaja telah menjadi masalah sosial di masyarakat. Perilaku seksual bermacam-macam mulai dari perasaan tertarik dengan lawan jenis, berkencan, berciuman, saling memegang bagian sensitif sampai bersenggama. Beberapa faktor yang dapat mempengaruhi perilaku seksual pranikah adalah pengetahuan dan kontrol diri. Remaja yang memiliki pengetahuan dan kontrol diri tinggi cenderung tidak melakukan perilaku seksual pranikah. Tujuan penelitian ini adalah untuk mengetahui adanya pengaruh pengetahuan dan kontrol diri terhadap perilaku seksual pranikah remaja SMK di Surabaya. Penelitian ini dilakukan menggunakan rancangan cross sectional. Populasi penelitian adalah seluruh siswa SMK kelas XI. Subjek ditarik dari populasi dengan proportional stratified random sampling. Sampel penelitian berjumlah 83 responden. Analisis data dilakukan menggunakan uji chi square $(\alpha=0.05)$. Hasil penelitian pengetahuan berpengaruh terhadap kontrol diri $(p=0.000$; $\mathrm{PR}=11.000)$, pengetahuan berpengaruh terhadap perilaku seksual pranikah $(\mathrm{p}=0.000 ; \mathrm{PR}=10.607)$ dan kontrol diri berpengaruh terhadap perilaku seksual pranikah $(p=0.000 ; P R=46.970)$. Kesimpulan dalam penelitian ini adalah variabel pengetahuan, kontrol diri mempengaruhi perilaku seksual pranikah remaja SMK di Surabaya. Untuk itu perlunya peningkatan pengetahuan remaja terkait dengan perilaku seksual pranikah melalui penyuluhan dalam Program Generasi Berencana (GENRE). Genre merupakan solusi alternatif untuk mengurangi perilaku seksual pranikah.
\end{abstract}

Kata kunci: Pengetahuan, Kontrol Diri, Perilaku Seksual Pranikah

\section{PENDAHULUAN}

Tingginya kasus kenakalan remaja yang menyimpang dari aturan yang berlaku di masyarakat diantaranya merokok, menggunakan obat terlarang, mengonsumsi alkohol, dan perilaku seks bebas pranikah (Stanhope dan Lancaster, 2004).Salah satu masalah kesehatan reproduksi remaja yang banyak diperhatikan 
adalah masalah perilaku seks bebas pranikah pada remaja. Tingginya angka kejadian perilaku pacaran remaja yang tidak sehat dapat mengarah pada perilaku seks bebas pranikah.

Hasil penelitian yang dilakukan oleh Survei Kesehatan Reproduksi Remaja (SKRR) yang dikutip dalam studi kasus (Israwati, 2013) menunjukkan bahwa usia pertama kali remaja Indonesia berpacaran yaitu pada usia 12 tahun. Perilaku pacaran remaja yang tidak sehat sebanyak $92 \%$ remaja pernah berpegangan tangan saat berpacaran, $82 \%$ remaja pernah melakukan ciuman, $63 \%$ remaja saling meraba bagian sensitive dengan pasangan pada saat pacaran. Adanya perilaku pacaran yang tidak sehat dapat menimbulkan remaja untuk mengarah pada hubungan seks bebas pranikah (Israwati, 2013).

Hasil survey (BKKBN, 2010) di Surabaya bahwa sebanyak $54 \%$ remaja perempuan sudah tidak memiliki keperawanan. Berdasarkan penelitian yang dilakukan oleh Sari (2014) mengenai bentuk perilaku pacaran remaja yang dilakukan di salah satu SMA di Surabaya didapatkan hasil bahwa sebanyak 90\% berpegangan tangan dengan mesra saat bersama pasangan, $78 \%$ berpelukan, Sebanyak $75 \%$ pernah berciuman, sebanyak $56 \%$ pernah saling meraba bagian sensitif, sebanyak $37 \%$ pernah melakukan petting, sebanyak $33 \%$ pernah oral seks, sebanyak $27 \%$ remaja mengaku sudah pernah melakukan hubungan seksual dengan pasangan. Semakin maraknya masalah kesehatan reproduksi yang terjadi di kalangan remaja, oleh sebab itu perlu adanya peningkatan pengetahuan, sikap dan aktivitas remaja dalam menjaga kesehatan reproduksinya.

Remaja dapat dikenal dengan istilah adolescence atau youth yang merupakan masa perubahan dari kanak-kanak ke masa dewasa yaitu antara usia 12-21 tahun. Adapun masa remaja terbagi dalam masa remaja awal yaitu berusia 12-15 tahun, masa remaja pertengahan yaitu berusia 15-18 tahun dan masa remaja akhir yaitu berusia 18-21 tahun (Monks, et al., 2002).

Perilaku seksual pranikah adalah salah satu bentuk ungkapan tingkah laku atau rasa cinta yang dilampiaskan dimulai pada tahap berdekatan, berciuman sampai melakukan senggama tanpa adanya ikatan pernikahan
(Hurlock, 2002). Dampak adanya perilaku seksual pranikah pada remaja adalah dapat menimbulkan rasa bersalah, takut, cemas, apabila terjadi kehamilan dapat dikucilkan di masyarakat, timbul perasaan malu dan depresi. Dampak fisiologis perilaku seksual pranikah adalah dapat mengakibatkan terjadinya kehamilan yang tidak diinginkan sehingga melakukan tindakan aborsi, dan tertular penyakit seksual seperti HIV AIDS, sifilis, (Sarwono, 2011). Faktor yang dapat mempengaruhi perilaku seksual pranikah diantaranya pengetahuan, kontrol diri (Sarwono, 2005). Adanya pengetahuan dan pemahaman tentang kesehatan reproduksi seksual remaja yang kurang disebabkan adanya sumber informasi yang salah (Soetjiningsih, 2004). Adanya pengetahuan kesehatan reproduksi seksual remaja yang benar, sehat dan terarah merupakan dasar bagi remaja dalam menentukan perilaku yang positif (April, 2010). Selain itu remaja juga dapat bertanggung jawab dalam menjaga fungsi reproduksinya secara benar dan sehat (Apri, 2010).

Menurut Ghufran (2010) kontrol diri adalah suatu kemampuan individu dalam mengarahkan dan mengontrol segala bentuk dorongan, perilakunya ke arah yang positif. Menurut (Chaplin, 2001) Kontrol diri adalah kemampuan individu dalam mengarahkan perilakunya ke arah yang lebih baik untuk mencapai suatu tujuan. Alasan remaja memiliki kebutuhan dalam mengontrol dirinya ialah adanya perubahan dalam kehidupan seksual.

Perubahan kehidupan seksual tersebut yang meliputi semakin maraknya media yang berkaitan dengan seksualitas sehingga memudahkan remaja dalam menggali informasi dan mengakses situs seksualitas, semakin banyaknya perilaku pacaran remaja tidak sehat yang dapat mengarah pada perilaku seksual, banyaknya penyakit yang ditimbulkan melalui hubungan seksual, sehingga berdampak pada semakin tingginya angka kejadian perilaku seksual pranikah (Suyasa, 2004).

Remaja yang mampu mengendalikan dirinya terhadap adanya dorongan seksual maka dapat berperilaku secara positif, tidak mudah terpengaruh adanya faktor luar. Seperti contohnya remaja tidak melanggar adanya larangan perilaku pacaran yang tidak sehat diantaranya ciuman sampai tindakan bersenggama (Sarwono, 2005). 
Diharapkan remaja dapat memiliki kontrol diri yang tinggi dan mampu mengarahkan perilakunya ke arah yang positif seperti menghindari kenakalan remaja yang meliputi; merokok, menggunakan obat terlarang dan alkohol, serta tindakan perilaku seksual pranikah. Tujuan penelitian ini adalah untuk mengetahui adanya pengaruh pengetahuan, kontrol diri terhadap perilaku seksual pranikah remaja SMK di Surabaya.

\section{METODE PENELITIAN}

Penelitian ini termasuk jenis penelitian analitik dengan menggunakan pendekatan cross sectional. Penelitian ini mengkaji pada variabel yang termasuk faktor risiko dan diobservasi secara langsung dalam waktu yang sama.

Populasi dalam kelompok kasus penelitian ini adalah seluruh remaja SMK di Surabaya kelas XI yang berjumlah 486 responden. Berdasarkan perhitungan besar sampel dalam penelitian ini maka didapatkan 83 responden dengan menggunakan Teknik Stratified Random Sampling atau pengambilan sampel secara acak stratifikasi. Sampel terdiri dari 4 strata yaitu kelas XI kejuruan akuntansi yang berjumlah 4 kelas, kelas XI kejuruan administrasi perkantoran yang berjumlah 5 kelas, kelas XI kejuruan tehnik komputer dan jaringan yang berjumlah 2 kelas, kelas XI kejuruan pengelolaan bisnis dan retail yang berjumlah 1 kelas. Penelitian ini dilakukan di sekolah SMK di Surabaya pada bulan November 2015-Februari 2016. Pada penelitian ini dilakukan pengolahan data dan di analisis menggunakan Chi Square dengan taraf kepercayaan $95 \%$.

\section{HASIL PENELITIAN}

\section{Karakteristik Responden}

Responden dalam penelitian ini berjumlah 83 responden. Adapun Karakteristik responden remaja SMK meliputi pada variabel jenis kelamin, variabel usia, variabel status tempat tinggal, variabel pengetahuan, variabel kontrol diri, dan variabel perilaku seksual pranikah. Berikut adalah tabel karakteristik responden.
Pada tabel 1 menjelaskan hasil penelitian karakteristik responden berdasarkan variabel jenis kelamin bahwa mayoritas responden pada remaja SMK adalah berjenis kelamin perempuan sebanyak $64,0 \%$. responden berdasarkan variabel usia menunjukkan mayoritas responden pada remaja SMK adalah berusia 16 tahun sebanyak $73 \%$. Karakteristik responden berdasarkan pada variabel status tempat tinggal menunjukkan mayoritas responden adalah tinggal bersama orang tua sebanyak $95 \%$.

Pada responden pada remaja SMK di Surabaya berdasarkan pada variabel pengetahuan kesehatan reproduksi seksual menunjukkan bahwa sebanyak 34\% responden memiliki pengetahuan yang baik dan sebanyak $66 \%$ responden remaja SMK memiliki pengetahuan yang kurang. Hasil penelitian menunjukkan bahwa mayoritas responden remaja SMK

Tabel 1. Karateristik Responden Berdasarkan Jenis Kelamin, Usia, Status Tempat Tinggal Pada Kalangan Remaja SMK di Surabaya

\begin{tabular}{|c|c|c|}
\hline Variabel & $\mathbf{N}$ & $\%$ \\
\hline \multicolumn{3}{|l|}{ Jenis Kelamin } \\
\hline Laki-laki & 30 & 36,0 \\
\hline Perempuan & 53 & 64,0 \\
\hline Total & 83 & 100 \\
\hline \multicolumn{3}{|l|}{ Usia Responden } \\
\hline 16 tahun & 61 & 73,0 \\
\hline 17 tahun & 22 & 27,0 \\
\hline Total & 83 & 100 \\
\hline \multicolumn{3}{|c|}{ StatusTempat Tinggal } \\
\hline Orang tua & 79 & 95,0 \\
\hline Keluarga & 3 & 4,0 \\
\hline Kost & 1 & 1,0 \\
\hline Total & 83 & 100 \\
\hline \multicolumn{3}{|c|}{ Pengetahuan Kesehatan } \\
\hline \multicolumn{3}{|c|}{ Reproduksi Seksual } \\
\hline Baik $>50 \%$ & 28 & 34,0 \\
\hline Kurang $\leq 50 \%$ & 55 & 66,0 \\
\hline Total & 83 & 100 \\
\hline \multicolumn{3}{|l|}{ Kontrol Diri } \\
\hline Tinggi $>50 \%$ & 51 & 61,0 \\
\hline Rendah $\leq 50 \%$ & 32 & 39,0 \\
\hline Total & 83 & 100 \\
\hline \multicolumn{3}{|l|}{ Perilaku Seksual } \\
\hline \multicolumn{3}{|l|}{ Pranikah } \\
\hline Risiko Tinggi & 51 & 61,0 \\
\hline Risiko Rendah & 32 & 39,0 \\
\hline Total & 83 & 100 \\
\hline
\end{tabular}


memiliki pengetahuan kesehatan reproduksi seksual yang kurang.

Karakteristik responden remaja SMK berdasarkan pada variabel kontrol diri menunjukkan bahwa 39\% responden memiliki kontrol diri yang rendah dan sebanyak $61 \%$ responden memiliki kontrol diri yang tinggi. Hasil penelitian menunjukkan bahwa mayoritas responden memiliki kontrol diri yang rendah dengan kategori tingkat pengetahuan yang kurang.

Karakteristik responden pada remaja SMK berdasarkan pada variabel perilaku seksual pranikah menunjukkan bahwa terdapat 32\% responden dengan perilaku seksual risiko rendah. Hasil penelitian menunjukkan bahwa mayoritas responden pada remaja SMK di Surabaya memiliki perilaku seksual risiko tinggi.

\section{Hasil Analisis Hubungan Antar Variabel Pegetahuan, Kontrol Diri Terhadap Perilaku Seksual Pranikah}

Pada tabel 2 menjelaskan hasil tabulasi silang antara variabel pengetahuan terhadap variabel kontrol diri, variabel pengetahuan terhadap perilaku seksual pranikah, variabel kontrol diri terhadap variabel perilaku seksual pranikah pada remaja SMK di Surabaya. Pada tabel tersebut menunjukkan hasil tabulasi silang dengan menggunakan analisis uji Chi Square yang dapat diperoleh nilai signifikan sebesar 0,001 artinya $\mathrm{p}$ value $<0,05$ bahwa pada remaja SMK yang memiliki pengetahuan kurang sebanyak $(90,9 \%)$ memiliki kontrol diri yang rendah dan remaja SMK tersebut memiliki 11 kali berisiko terpapar kontrol diri yang rendah. Berikut adalah tabulasi silang antara variabel

Tabel 2. Tabulasi Silang Pengaruh Pengetahuan, Kontrol Diri terhadap Perilaku Seksual di Kalangan Remaja SMK di Surabaya

\begin{tabular}{|c|c|c|c|c|c|c|}
\hline \multirow{3}{*}{ Pengetahuan } & \multicolumn{4}{|c|}{ Kontrol Diri Remaja } & \multirow{2}{*}{\multicolumn{2}{|c|}{ Jumlah }} \\
\hline & \multicolumn{2}{|c|}{ Tinggi $>\mathbf{5 0} \%$} & \multicolumn{2}{|c|}{ Rendah $\leq \mathbf{5 0} \%$} & & \\
\hline & $\mathbf{n}$ & $\%$ & $\mathbf{n}$ & $\%$ & $\mathbf{N}$ & $\%$ \\
\hline Baik $>50 \%$ & 28 & 100 & 0 & 0,0 & 28 & 100,0 \\
\hline Kurang $\leq 50 \%$ & 5 & 9,1 & 50 & 90,9 & 55 & 100,0 \\
\hline Jumlah & 33 & 39,8 & 50 & 60,2 & 83 & 100,0 \\
\hline \multicolumn{7}{|c|}{$X^{2}$ hitung $=60,283 p=0,001<(\alpha=0,05)$ Rasio Prevalensi $=11,000$} \\
\hline \multirow{3}{*}{ Pengetahuan } & \multicolumn{4}{|c|}{ Perilaku Seksual Pranikah } & \multirow{2}{*}{\multicolumn{2}{|c|}{ Jumlah }} \\
\hline & \multicolumn{2}{|c|}{ Risiko Rendah } & \multicolumn{2}{|c|}{ Risiko Tinggi } & & \\
\hline & $\mathbf{n}$ & $\%$ & $\mathbf{n}$ & $\%$ & $\mathbf{N}$ & $\%$ \\
\hline Baik $>50 \%$ & 27 & 96,4 & 1 & 3,6 & 28 & 100,0 \\
\hline Kurang $\leq 50 \%$ & 5 & 9,1 & 50 & 90,9 & 55 & 100,0 \\
\hline Jumlah & 32 & 38,6 & 51 & 61,4 & 83 & 100,0 \\
\hline \multicolumn{7}{|c|}{$X^{2}$ hitung $=56,112 \mathrm{p}=0,001<(\alpha=0,05)$ Rasio Prevalensi $=10,607$} \\
\hline \multirow{3}{*}{ Kontrol Diri } & \multicolumn{4}{|c|}{ Perilaku Seksual Pranikah } & \multirow{2}{*}{\multicolumn{2}{|c|}{ Jumlah }} \\
\hline & \multicolumn{2}{|c|}{ Risiko Rendah } & \multicolumn{2}{|c|}{ Risiko Tinggi } & & \\
\hline & n & $\%$ & $\mathbf{n}$ & $\%$ & $\mathbf{N}$ & $\%$ \\
\hline Tinggi $>50 \%$ & 31 & 93,9 & 2 & 6,1 & 33 & 100,0 \\
\hline Rendah $\leq 50 \%$ & 1 & 2,0 & 49 & 98,0 & 50 & 100,0 \\
\hline Jumlah & 32 & 38,6 & 51 & 61,4 & 83 & 100,0 \\
\hline
\end{tabular}


pengetahuan terhadap variabel kontrol diri, variabel pengetahuan terhadap perilaku seksual pranikah, variabel kontrol diri terhadap variabel perilaku seksual pranikah pada remaja SMK di Surabaya dapat dilihat pada Tabel 2.

Pada remaja dengan pengetahuan yang rendah sebanyak $(90,9 \%)$ memiliki perilaku seksual pranikah risiko tinggi dan 10 kali berisiko terpapar perilaku seksual pranikah risiko tinggi. Pada remaja dengan kontrol diri rendah sebanyak $(93,9 \%)$ memiliki perilaku seksual pranikah risiko tinggi dan 46 kali berisiko terpapar perilaku seksual pranikah dengan risiko tinggi.

\section{PEMBAHASAN}

Pada penelitian ini menggunakan metode analisis Chi Square yang diterapkan untuk mengetahui adanya pengaruh pengetahuan, kontrol diri terhadap perilaku seksual pranikah pada remaja SMK di Surabaya.

\section{Pengaruh Pengetahuan Terhadap Kontrol Diri Remaja SMK di Surabaya}

Berdasarkan hasil analisis tabulasi silang menjelaskan bahwa remaja dengan pengetahuan yang rendah memiliki kontrol diri yang rendah yaitu sebanyak 50 (90,9\%). Kurangnya pengetahuan remaja tentang kesehatan reproduksi seksual dapat menyebabkan salah persepsi tentang informasi seksual dari sudut pandang para remaja. Hasil analisis dengan menggunakan uji Chi Square menyatakan bahwa terdapat pengaruh pengetahuan terhadap kontrol diri pada remaja SMK di Surabaya.

Menurut (Notoadmodjo, 2003) pada remaja yang mempunyai pemahaman informasi kesehatan reproduksi seksual secara benar dan akurat maka remaja tersebut cenderung memiliki risiko perilaku seksual pranikah dengan risiko rendah. Pada remaja yang memiliki pengetahuan baik tentang kesehatan reproduksi seksual, maka remaja tersebut mampu mengendalikan diri nya dalam menekan timbulnya dorongan seksual yang timbul dalam dirinya, baik yang timbul adanya pengaruh dari luar maupun dari dalam individu tersebut. Pada umumnya remaja memiliki rasa ingin tahu yang tinggi atau disebut dengan (high curiousity).
Di usia remaja cenderung ingin mencari pengalaman dengan melakukan penjelajahan terhadap segala sesuatu yang baru serta remaja mempunyai keinginan untuk mencoba segala sesuatu yang belum pernah dialaminya. Selain didorong oleh keinginan menjadi seperti orang dewasa dapat menyebabkan remaja ingin mencoba melakukan apa yang sering dilakukan orang dewasa termasuk yang berkaitan dengan masalah seksualitas (Azwar A, 2000).

Adanya dorongan seksual yang timbul dapat dikendalikan remaja dengan cara mengalihkan pikiran yang positif, artinya tidak memikirkan hal yang dapat mendorong gairah seksualnya yang muncul. Pengetahuan yang rendah pada remaja yang tidak ditunjang dengan pemahaman yang benar dapat memperlemah kontrol diri pada remaja. Kontrol diri yang rendah disebabkan karena remaja hanya ingin memenuhi rasa ingin tahunya tanpa mempertimbangkan dampak yang timbul.

Menurut (Helmi dan Parasmastri, 1998) selain itu penyebab lain adalah kurang nya keterbukaan informasi tentang seksual yang benar dan sehat, bahkan terdapat anggapan masyarakat bahwa seksual merupakan hal yang tabu untuk diperbincangkan secara terbuka. Pengetahuan yang rendah akan memicu remaja menjadikan pencarian referensi seksual pranikah melalui media massa maupun media elektronik yang menyebar secara bebas di kalangan remaja.

\section{Pengaruh Pengetahuan terhadap Perilaku Seksual Remaja SMK di Surabaya}

Berdasarkan hasil penelitian mengenai pengaruh pengetahuan terhadap kejadian perilaku seks bebas pada remaja SMK "KTT" di Surabaya bahwa remaja dengan perilaku seks bebas risiko tinggi yang memiliki kategori pengetahuan yang kurang sebanyak $50(90,9 \%)$. Hasil analisis dengan uji Chi Square bahwa terdapat pengaruh pengetahuan terhadap perilaku seks bebas pranikah pada remaja SMK di Surabaya.

Perilaku ialah suatu perbuatan atau tingkah laku yang diperbuat oleh individu sendiri yang dapat diamati secara langsung ataupun tidak dapat dilihat dengan tidak langsung (Notoatmodjo, 2007). Pengetahuan hasil dari mengerti atau faham pada seseorang melalui panca indra 
terhadap hal tertentu. Pengetahuan merupakan sesuatu yang mendasari seseorang dalam suatu tindakan (Notoatmodjo, 2007). Seperti yang ada dalam teori PRECED - PROCEED yang dikembangkan oleh Lawrence Green bahwa perilaku individu yang menyangkut kesehatan ditentukan oleh pengetahuan yang dimilikinya, serta dapat menimbulkan perubahan dalam berperilaku (Notoatmodjo, 2010).

Menurut (Rahwamati, 2008) pola perilaku seksual dibagi menjadi dua macam menjadi Pertama, perilaku seksual secara individu meliputi masturbasi, dan berfantasi seksual. Masturbasi adalah suatu tindakan memegang bagian tubuh yang sensitif dengan tujuan merangsang dirinya tanpa adanya hubungan kelamin untuk mendapatkan kepuasan seksual. Masturbasi ini dapat dilakukan dengan menggunakan alat bantuan seperti jari tangan yang dimasukkan alat kelamin. Masturbasi merupakan gejala umum yang dilakukan oleh remaja. berfantasi seksual merupakan perilaku berhayal bahwa terdapat pasangan untuk menjadi lawan dalam berperilaku seksual. Perilaku tersebut dapat menimbulkan kepuasaan serta dapat menimbulkan rasa ketagihan. Kedua, perilaku seksual dengan pasangan baik pada wanita dengan wanita, wanita dengan lelaki yang melibatkan tindakan pelukan, ciuman, petting, sampai bersenggama.

Menurut (Chronika, 2011) bentuk perilaku seksual pranikah, meliputi: ciuman, berpelukan, saling meraba bagian sensitif (payudara, alat kelamin), petting atau saling menempelkan alat kelamin, bersenggama atau berhubungan seksual tanpa adanya ikatan pernikahan. Pada variabel ini responden mengisi beberapa pertanyaan berjumlah 14. Pertanyaan tersebut dijawab berdasarkan pengalaman pada saat bersama pasangan dan sampai sejauh mana perilaku pacaran remaja yang meliputi bentuk perilaku seksual pranikah yang meliputi berfantasi seksual, berciuman, pelukan, saling memegang bagian sensitif, saling menempelkan alat kelamin, bersenggama atau berhubungan seksual tanpa adanya ikatan pernikahan.

Perkembangan jaman saat ini, ikut mempengaruhi perilaku seksual dalam berpacaran remaja. Hal ini misalnya dapat dilihat bahwa hal-hal yang ditabukan oleh remaja pada beberapa tahun yang lalu, seperti berciuman dan bercumbu kini telah dibenarkan oleh remaja sekarang. Bahkan ada sebagian kecil dari mereka setuju dengan free sex. Kondisi tersebut cukup mengkhawatirkan mengingat perilaku tersebut dapat menyebabkan Kasus Kehamilan Tidak Diinginkan (KTD) yang selanjutnya memicu praktik aborsi yang tidak aman, penularan PMS dan HIV/AIDS, bahkan kematian (DeLamater, 2007).

Menurut (Kurniasari, 2007) Informasi pengetahuan kesehatan reproduksi remaja diberikan dalam bentuk pendidikan seksual. Pendidikan seksual ialah suatu cara untuk mencegah remaja dalam pergaulan bebas atau penyalahgunaan seksualitas, serta untuk mencegah dampak negatif yang timbul. Meskipun terdapat anggapan bahwa seksualitas merupakan hal yang tabu untuk diperbincangkan.

Pandangan tentang pendidikan seksualitas sebenarnya tergantung dari cara individu sendiri dalam mengartikannya. pendidikan seksualiatas tidak hanya menjelaskan mengenai seksualiatas tetapi juga menjelaskan aturanaturan yang berlaku di masyarakat mengenai hal apa saja yang dilarang di dalam lingkungan masyarakat. Adanya pengetahuan seksual yang baik diharapkan remaja dapat mencegah adanya perilaku seksual pranikah yang dapat menyebabkan terjadinya kehamilan yang tidak diinginkan, tingginya angka kejadian aborsi yang tidak aman, serta menularnya penyakit kelamin pada remaja. Seperti yang diungkapkan oleh Darmasih (2009) semakin tinggi pengetahuan tentang kesehatan reproduksi seksual yang dimiliki remaja maka semakin rendah perilaku seksualnya. Sebaliknya jika semakin tinggi perilaku seksual pranikah maka semakin rendah pengetahuan tentang kesehatan reproduksi seksual yang dimiliki oleh remaja. Pengetahuan akan meningkat jika individu mendapatkan informasi dengan benar dan bertanggung jawab Notoatmodjo (2003). Dengan adanya pengetahuan yang meningkat dapat menyebabkan seseorang untuk berperilaku yang sesuai dengan pengetahuan yang dimilikinya.

Pada individu yang memperoleh pengetahuan dengan setengah-setengah akan berakibat lebih berbahaya jika dibandingkan pada individu yang tidak tahu sam sekali. Adapun faktor internal dan eksteral yang mempengaruhi dalam membentuk 
pengetahuan dalam diri. Faktor internal meliputi bagaimana cara individu menanggapi pengetahuan yang diperoleh tersebut, sedangkan pada faktor adalah rangsangan atau stimulus dalam mengubah pengetahuan yang diperoleh untuk menjadi lebih baik dan bermanfaat (Darmasih, 2009).

Menurut Rodiyah (2004), bahwa semakin canggihnya teknologi dapat memberikan peluang bagi remaja untuk mendapatkan informasi tentang seksualitas. Remaja tidak hanya mendapatkan informasi dari orang dan teman, tetapi remaja juga bisa mendapat informasi seksualitas dari media massa yang belum tentu benar dan akurat. Adanya hal tersebut dapat memudahkan remaja untuk mendapatkan informasi secara luas dan bebas namun tanpa melihat risiko yang timbul bahkan tanpa melihat ketidak benaran dari sumber informasi yang di dapat. Pandangan tentang pendidikan seksualitas sebenarnya tergantung dari cara individu sendiri dalam mengartikannya. pendidikan seksualitas tidak hanya menjelaskan mengenai seksualitas saja akan tetapi juga menjelaskan aturanaturan yang berlaku di masyarakat mengenai hal apa saja yang dilarang di dalam lingkungan masyarakat. Adanya pengetahuan seksual yang baik diharapkan remaja dapat mencegah adanya perilaku seksual pranikah yang dapat menyebabkan terjadinya kehamilan yang tidak diinginkan, tingginya angka kejadian aborsi yang tidak aman, serta menularnya penyakit kelamin pada remaja.

Seperti yang diungkapkan oleh Darmasih et al., (2011) semakin tinggi pengetahuan tentang kesehatan reproduksi seksual yang dimiliki remaja maka semakin rendah perilaku seksualnya. Sebaliknya jika semakin tinggi perilaku seksual pranikah maka semakin rendah pengetahuan tentang kesehatan reproduksi seksual yang dimiliki oleh remaja. Pengetahuan akan meningkat jika individu mendapatkan informasi dengan benar dan bertanggung jawab Notoatmodjo (2003). Dengan adanya pengetahuan yang meningkat dapat menyebabkan seseorang untuk berperilaku yang sesuai dengan pengetahuan yang dimilikinya. Pada individu yang memperoleh pengetahuan dengan setengahsetengah akan berakibat lebih berbahaya jika dibandingkan pada individu yang tidak tahu sama sekali.

Kecenderungan remaja dalam menerima informasi dari teman sebayanya tanpa adanya dasar sumber informasi yang jelas, terarah dan mengenai kesehatan reproduksi seksual, dapat mengakibatkan rasa penasaran dan ingin tahu yang membentuk serangkaian pertanyaan dalam diri remaja (Santor, 2000). Untuk menjawab pertanyaan itu serta membuktikan informasi yang diterima, maka remaja cenderung melakukan dan mengalami perilaku seks pranikah itu sendiri. Menurut BKKBN (2000) pembekalan pengetahuan remaja meliputi: perkembangan fisik, psikis dan kematangan seksual yang mempunyai fungsi adalah agar remaja lebih mudah dalam memahami dan mengatasi perubahan yang terjadi dalam dirinya, proses reproduksi yang bertanggung jawab adalah perlunya remaja dalam mengendalikan diri tentang seksualitasnya serta menyalurkannya dalam kegiatan yang positif seperti olahraga dan mengaji, hubungan pergaulan yang sehat antara remaja pria dan wanita serta dapat membentengi dirinya dari masalah remaja yang terjadi di sekitar lingkungannya, persiapan pranikah adalah pemberian pengetahuan atai informasi mengenai hal yang penting baik mental, emosional dalam menghadapi kehidupan berkeluarga, pada remaja wanita perlunya pembekalan informasi tentang kehamilan dan persalinan.

Adapun faktor internal dan eksteral yang dapat mempengaruhi remaja dalam membentuk pengetahuan yang ada dalam dirinya. Faktor dari dalam meliputi bagaimana cara remaja menanggapi pengetahuan yang diperoleh tersebut, sedangkan pada faktor luarnya adalah rangsangan atau stimulus dalam mengubah pengetahuan yang diperoleh remaja dalam bersikap serta berperilaku menjadi lebih baik dan bermanfaat, (Darmasih, 2009).

Menurut Darmasih (2009) pengetahuan remaja yang baik adalah remaja yang memahami mengenai arti perilaku seksual pranikah dengan benar dan terarah. Manfaat pengetahuan seksual yang dimiliki remaja ialah remaja dapat memahami tentang perbedaan kesehatan reproduksi pada perempuan dan pria baik dalam lingkungan pekerjaan, keluarga, 
dan lingkungan sekitar yang dapat berubahubah menurut kebudayaan atau adat setempat, paham tentang peranan kesehatan reproduksi dalam kehidupan manusia dan keluarga, mengaplikasikan pengertian mengenai dirinya sendiri sesuai dengan kebutuhan seksualnya, mampu mengambil keputusan yang bertanggung jawab dengan segala bentuk resikonya, (Sarwono, 2003). Dapat disimpulkan bahwa pada remaja dengan pengetahuan yang tinggi maka remaja tersebut memiliki perilaku seksual risiko rendah. Serta mampu dalam berperilaku pacaran yang sehat dan tidak mengarah pada adanya tindakan seksual.

\section{Pengaruh Kontrol Diri terhadap Perilaku Seksual Pranikah Remaja SMK di Surabaya}

Berdasarkan hasil penelitian tentang pengaruh kontrol diri terhadap kejadian perilaku seks bebas pranikah dapat disimpulkan bahwa mayoritas responden dengan kontrol diri yang rendah memiliki perilaku seksual risiko tinggi sebanyak 50 responden $(98,0 \%)$. Hasil analisis dengan uji Chi Square menunjukkan bahwa terdapat pengaruh kontrol diri terhadap perilaku seks bebas pranikah pada remaja SMK di Surabaya.

Menurut Gunarsa (2004), kontrol diri ialah suatu kemampuan individu dalam menahan keinginan yang bertolak belakang dengan tingkah laku yang tidak sesuai dengan peraturan yang ada. Menurut (Mahfiana, 2009) dalam penelitiannya menjelaskan bahwa kontrol diri yang kurang pada remaja menjadi salah satu penyebab maraknya perilaku seksual pranikah yang menyimpang dari norma agama. Berawal dari perkenalan, menjalin hubungan dengan lawan jenis (pacaran), perilaku pacaran yang dimulai dari gandengan tangan sampai menjurus pada perilaku seksual. Seperti yang diungkapkan oleh Sulistijo (2002) dalam penelitiannya bahwa semakin tinggi seorang individu dalam mengontrol dirinya maka akan semakin mampu dalam mencegah dirinya terjerumus dalam tindakan seksual.

Menurut Dariyo (2004) Remaja yang memiliki kontrol diri yang tinggi akan mempunyai kemampuan untuk menyesuaikan diri dalam lingkungan yang baik dan tindakan yang positif. Artinya segala informasi baik yang diterima maupun ditolak tergantung dari kontrol diri yang dimiliki oleh seseorang individu tersebut individu yang memiliki kontrol diri yang baik akan memiliki kemampuan dalam penyesuaian diri dengan lingkungan sosial dengan baik.

Hasil penelitian ini menunjukkan bahwa semakin rendah kontrol diri yang dimiliki, maka akan semakin tinggi perilaku seksual pranikah pada remaja. Hal ini sejalan dengan penelitian yang dilakukan oleh Safitri (2007) yang menyatakan bahwa kontrol diri memberikan pengaruh sebesar $12,5 \%$ terhadap perilaku seksual pranikah dan sisanya dipengaruhi oleh berbagai faktor lain. Penelitian lain oleh Khairunisa (2013) yang berhubungan dengan kontrol diri dan perilaku seksual pranikah yang menyatakan bahwa ada hubungan yang signifikan antara perilaku seksual pranikah dengan kontrol diri.

Kontrol diri yang rendah pada remaja dapat menimbulkan perilaku seksual risiko tinggi. Hal ini di dukung oleh Boyke. Pada remaja yang berkonsultasi dengan dokter boyke mengakui pernah berhubungan seksual pranikah mengalami kenaikan sebanyak 16-20\%jika dibandingkan pada tahun 1980 hanya sebanyak 5-10\% (Safitri, 2007).

Kontrol diri berhubungan dengan cara seorang individu dalam mengendalikan emosi atau dorongan yang timbul dalam dirinya. Oleh karena itu pada saat seseorang memiliki kontrol diri tinggi terhadap dorongan seksual dari dalam diri maupun yang datang dari luar maka individu tersebut memiliki kontrol terhadap perilaku seksualnya sehingga mencegah dirinya terjerumus dalam terjadinya perilaku permisif terhadap adanya perilaku seksualnya.

Menurut Sarwono (2010), remaja yang mempunyai kontrol diri yang tinggi, dapat mengalihkan pada kegiatan atau perilaku yang bermanfaat seperti olah raga, aktif terlibat dalam kegiatan sosial yang ada di masyarakat seperti kegiatan karang taruna, REMAS (Remaja Masjid), mengaji. Dengan semakin banyaknya kegiatan bermanfaat yang dimiliki remaja dapat meminimalkan adanya perilaku yang negatif dalam bentuk apapun seperti merokok, menggunakan obat terlarang dan alkohol, perilaku seksual pranikah. Faktor yang dapat mempengaruhi timbulnya perilaku seksual adalah 
meningkatnya libido dalam seksualitas, umur perkawinan yang tertunda, pengetahuan yang kurang serta semakin banyaknya faktor luar yang mempengaruhi seperti semakin banyaknya pergaulan bebas (Soetjiningsih, 2010).

Pada remaja dengan kontrol diri yang rendah maka cenderung akan membutuhkan pengakuan dari lawan jenis atau ingin dikagumi. Adanya perkembangan hormonal yang cepat pada remaja tanpa didasari dengan adanya pengetahuan yang cukup mengenai kesehatan reproduksi seksual remaja dapat menyebabkan remaja kurang mampu mengendalikan diri atas peningkatan libidonya (Dariyo, 2004).

Menurut (Dariyo, 2004) Remaja yang memiliki pengetahuan yang benar dan terarah tentang kesehatan reproduksi seksual jika tidak diimbangi dengan kontrol diri yang tinggi maka akan terjerumus dalam perilaku seksual pranikah yang tidak sehat.

Hurlock (2002) menjelaskan bahwa adanya kontrol diri dipengaruhi oleh faktor internal dan faktor eksternal. Faktor internal adalah faktor yang berasal dari individu sendiri, misalnya pengetahuan, usia (semakin usia individu bertambah maka semakin tinggi kemampuan individu dalam mengontrol dirinya), emosi, kepribadian sedangkan faktor eksternalnya adalah lingkungan.

Menurut Calhoun dan Accocela (2004) alasan individu harus mengontrol dirinya adalah karena individu tidak hidup sendiri, melainkan dalam suatu kelompok baik pada kelompok lingkungan masyarakat maupun lingkungan teman sebaya. Pada hal ini individu memiliki kebutuhan dalam memuaskan apa yang dikehendakinya. Oleh karena itu individu perlu mengontrol dirinya atau mempunyai kontrol diri yang tinggi agar melanggar aturan yang berlaku dan tidak mengganggu kenyamanan di lingkungan sekitar. Apabila individu melakukan hal tersebut maka masyarakat atau teman sebaya akan menghargai dan menerima hal-hal yang dimiliki oleh individu.

Dapat ditarik kesimpulan bahwa pada remaja yang memiliki kontrol diri yang tinggi maka remaja tersebut memiliki perilaku seksual dengan risiko rendah. Sebaliknya pada remaja yang memiliki kontrol diri yang rendah maka remaja tersebut memiliki perilaku seksual dengan risiko tinggi.

\section{SIMPULAN \& SARAN}

\section{Simpulan}

Berdasarkan hasil dan pembahasan dalam penelitian ini dapat disimpulkan bahwa berdasarkan hasil analisis dengan menggunakan metode Chi Square adalah terdapat pengaruh pengetahuan, kontrol diri terhadap perilaku seksual pranikah remaja SMK di Surabaya.

\section{Saran}

Hasil penelitian menyarankan adanya pendidikan mengenai Program Generasi Berencana (GENRE) di sekolah yang diberikan kepada remaja sejak dini. Peningkatan kesadaran masyarakat tentang pentingnya Program Bina Keluarga Berencana (BKR), yang di dukung kebijakan pemerintah dalam pemblokiran situs yang berhubungan dengan seksualitas. Perlunya kerja sama melalui lintas sektoral yang menghubungkan antara pihak pemerintah, sekolah dan BKKBN dalam menjalankan program yang terkait dengan kesehatan reproduksi seksual pada remaja.

\section{DAFTAR PUSTAKA}

Apri, S. 2010. Hubungan Lingkungan Pergaulan dan Tingkat Pengetahuan tentang Kesehatan Reproduksi dengan Sikap Seks Bebas pada Remaja. Skripsi: Universitas Sebelas Maret Surakarta.

Azwar, A. 2000. Kesehatan Reproduksi Remaja di Indonesia (Adolescent Reproductive Health in Indonesia).

BKKBN. 2010. Penyiapan Kehidupan Berkeluarga bagi Remaja. Direktorat Remaja dan Perlindungan Hak-hak Reproduksi. Jakarta.

Calhoun, J.F., and Acocella, J.R. 2004. Psikologi Tentang Penyesuaian dan Hubungan Kemanusiaan (Terjemahan oleh Satmoko, R.S.) Edisi ketiga. Semarang: Penerbit IKIP Semarang.

Chaplin, J.P. 2001. Kamus Lengkap Psikologi (Terjemahan Kartini Kartono). Jakarta: Raja Grafindo Perkasa

Chronika, R. 2011. Makna Seks Bebas Bagi Pelajar SMP di Kota Padang. Skripsi: Universitas Andalas Padang. 
Dariyo, A. 2004. Psikologi Perkembangan Remaja. Jakarta: Ghalia Indonesia.

Darmasih, R. 2009. Faktor yang Memengaruhi Perilaku Seks Pranikah Pada Remaja Sma di Surakarta. Skripsi: Universitas Muhammadiyah Surakarta.

DeLamater, John dan Sara M. Moorman. 2007. Sexual Behavior in Later Life. Journal of Aging and Health, 20(10): 1-25.

Ghufron, M. Nur \& Rini Risnawita S. 2010. TeoriTeori Psikologi. Yogyakarta: Ar-Ruzz media.

Gunarsa, S. 2004. Dari Anak Sampai Usia Lanjut. Bunga Rampai Psikologi Perkembangan. Jakarta: PT BPK Gunung Mulia.

Helmi, F.D dan Paramastri, I. 1998. Efektivitas Pendidikan Seksual Dini dalam Meningkatkan Pengetahuan Perilaku Seksual Sehat.Jurnal Psikologi. Universitas Gadjah Mada. No. 2, 25-34.

Hurlock, E.B. 2002. Psikologi Perkembangan, Suatu Pendekatan Sepanjang Rentang Kehidupan (terjemahan Istiwidayanti dan Soedjarwo). Jakarta: Erlangga.

Israwati. 2013. Perilaku Seks Pra-Pranikah Mahasiswa pada Sekolah Tinggi Manajemen Informatika dan Komputer Bina Bangsa Kendari. (Studi Kasus). Skripsi: Universitas Hasanuddin.

Khairunnisa, A. 2013. Hubungan Religiusitas dan Kontrol Diri dengan Perilaku Seksual Pranikah Remaja di MAN 1 Samarinda. eJournal Psikologi. Volume 1. Nomor 2; 220-229

Kurniasari, M.D. 2007. Faktoryang Memengaruhi Perilaku Seksual di Kalangan Mahasiswa. Skripsi: Universitas Airlangga.

Mahfiana, L. Rohmah, E. Y. dan Widyaningrum, R. 2009. Remaja dan Kesehatan Reproduksi. Ponorogo: Stain Press.

Monks F.J., Knoers A.M.P., Haditono S.R., 2002. Psikologi Perkembangan Pengantar dalam
Berbagai Bagiannya, Edisi Keempat Belas. Yogyakarta: Gadjah Mada University Press.

Notoadmodjo, S. 2010. Pendidikan dan Perilaku Kesehatan. Jakarta: PT. Rineka Cipta.

Rahmawati, D.A. 2008. Potret Perilaku Sari, T,R. 2014. Perilaku Seksual Remaja Siswa SMK Ketintang Surabaya. Volume 04 Nomor 03; 1-9.

Rina, A. 2012. Hubungan Antara Kontrol Diri dengan Sikap terhadap Perilaku Seksual pada Remaja Karang Taruna. Naskah Publikasi: Universitas Muhammadiyah Surakarta.

Sarwono, W,S. 2011. Psikologi Remaja. Edisi revisi cetakan 14. Jakarta: PT. Rajawali Grafindo Persada.

Santor, D.A., Messervery, D., Kusumakar, V. 2000. Measuring Peer Pressure, Popularity and Conformity in Adolescent Boys and Girls: Predicting School Performance, Sexual Attitude, and Substances Abuse. Journal of Youth and Adolescence. 29(2): 163-182.

Safitri, E. 2007. Hubungan Kontrol Diri dengan Perilaku Seksual Remaja. (Naskah Publikasi). Skripsi: Fakultas Psikologi dan Ilmu Sosial Budaya Universitas Islam Indonesia Yogyakarta.

Sari, T,R. 2014. Perilaku Seksual Remaja Siswa SMK Ketintang Surabaya. Volume 04 Nomor 03; 1-9.

Soetjiningsih dkk. 2004. Buku Ajar: Tumbuh Kembang Remaja dan Permasalahan nya. Jakarta: Sagung Seto.

Stanhope and Lancaster, 2004. Community Health Nursing: $4^{\text {th }}$ Edition. Mosby Co St. Louis Missouri: 167-170.

Sulistijo, E. 2002. Hubungan antara Kontrol Diri dengan Kecenderungan.

Seksual Remaja Perempuan di Perkotaan. Skripsi: Universitas Airlangga.

Suyasa, P.T.Y. 2004. Pengendalian Diri pada Remaja. Jakarta: Gunung Mulia. 